\title{
A Study on the Flipped Classroom and Its Application in College English Teaching
}

\section{Chen Yanhua}

College of Foreign Languages, Zhoukou Normal University, Zhoukou City, Henan Province, 466000, China

Keywords: Flipped classroom; College English; English teaching; Application

\begin{abstract}
With the rapid progress of information technology, the education circle experiences a historical diversified change by following the footstep of informatization. Since the flipped classroom appeared, it has aroused the growing concern of the domestic and international education sector. Some countries and regions have launched a revolution in classroom teaching. However, the application of flipped classroom in college English teaching in China is not common. Based on the author's learning and teaching experience, this paper first analyzed the key elements in the flipped classroom and then put forward the specific operation of the flipped classroom in instructing college English teaching.
\end{abstract}

\section{Introduction}

In recent years, the flipped classroom, a kind of teaching model that overturns the traditional model, draws more and more people's attention. In a short time, this model has attracts a lot of enthusiasm in the world and it is famous for changing the traditional teaching process. The flipped classroom changes the traditional teaching model and the teaching is no longer limited to time and space, so that students can learn at any time and any place[1]. The knowledge that needs to be taught in class is advanced to the class beforehand and the knowledge internalization is advanced to the class. Students' independent learning has been strengthened and the knowledge internalization has been optimized.

\section{The Key Elements in the Flipped Classroom}

\subsection{The production of videos before class}

The flipped classroom requires teacher to prepare teaching videos in advance and allows students to watch them before class. The video design and production is the prerequisite for the success of the flipped classroom. Videos can be made personally by teachers and teachers can also use high-quality resources in the open network. If the teacher produces videos personally, they should make teaching objectives clear and targeted, which will take into account of the individual differences between students, so that teachers can teach students in accordance of their aptitude. Another approach is to find desired videos in the open network. The resources in the open network is rich and each knowledge point is equipped with the relevant teaching videos, learning materials and homework. There are pros and cons of the two approaches and teachers can intersect the two approaches. Teaching videos should be terse, forceful, closely related to teaching objectives and requirements, and interesting, so as to attract students' attention and interest. Moreover, videos should be educational, vivid, creative, easy to understand and exciting. The wonderful video is a good start to the flipped classroom and can lay a good foundation for classroom activities to ensure the success of the flipped classroom.

\subsection{The organization of classroom activities}

The classroom activity is the key to the success of the flipped classroom, whose goal is to promote the internalization of students' knowledge with various forms of teaching activities. Classroom activities are no longer a single process to transfer and infuse knowledge and students are 
not passive to listen to and accept the knowledge. The classroom becomes a place where teachers and students can communicate with each other, exchanges with each other and learn from each other. The classroom is a place for teachers to cultivate the comprehensive integration and development of students' knowledge, skills, emotions and attitudes. This requires teachers to plan teaching elaborately and reasonably organize various activities for students in accordance with the teaching objectives and requirements. In the design and organization of classroom activities, teachers can design classroom activities where students can interact with each one based on students' mastery of videos. These activities include consolidation exercise, restraining doubts, role playing, group discussions and collaborative learning. Through these activities, the classroom becomes a place where students can acquire a wide range of knowledge, develop their abilities, cultivate appropriate emotions and form correct attitudes and values.

\subsection{The role of teachers}

The flipped classroom is a new concept and the combined product of new technology and it breaks the boundary of the traditional classroom. The flipped classroom overturns the classroom teaching process. Students is no longer to listen to the explanation in the class, but watch videos before class; they do not do exercises after school, but do homework in the class. The flipped classroom breaks the limitations of time and space, so students can learn at any time and any place according to their own interests and needs. This kind of classroom model has changed the traditional teacher's infusing role in the classroom and promotes the substantial change of teacher's role. This requires teachers to change the traditional role to adapt to this new teaching model. In the flipped classroom, teachers should design wonderful videos and design related questions, so they are designers and producers of these videos; they should organize various forms of activities, answer questions raised by students and communicate with students, so teachers should be designers, organizers and managers of classroom activities. In this process, teachers should participate in these activities and promote students' knowledge internalization, so teachers should also be participants and facilitators for students' learning.

\section{The Specific Operation of the Flipped Classroom in Instructing College English Teaching}

\subsection{To define teachers' role and orientation}

In the flipped classroom teaching model, college English teachers should complete the transition from teacher-centered teaching to student-centered teaching in the whole process of college English teaching. Teachers must first adjust the mentality and change the concept. They should approve the new relationship between teachers and students in perception that teachers and students are equal; they should eliminate the concept of hierarchy and release from the almost absolute right of speech. Teachers are no longer the authority to impart knowledge, but instructors to help students to conduct independent learning and answer their questions. As the guider, teachers need to understand each student's internal potential and advantages of intelligence, master the difference between their learning and understanding of knowledge and grasp how to provide students with differentiated one-on-one counseling in the classroom. Teachers should know how to solve each student's problems and answer their questions within limited time and space to promote the development of their personality, so they should abandon the original stereotyped popular teaching. These changes have posed great challenges to teachers. Therefore, teachers need to improve their ability to master the business and have the excellent all-round guidance ability.

\subsection{To improve information technology literacy of teachers and students}

Nowadays, the increasing popularity of computers, the extensive application of the Internet and the rapid development of cloud technology have made our life into the era of big data. Information technology has infiltrated into every field of life quietly and the education sector has not escaped from this revolution. In order to apply the flipped classroom successfully in college English teaching 
practice, both teachers and students should improve their own information technology literacy and computer application skills. First of all, the production of teaching videos has put forward higher requirements on teachers' information technology. Only teachers master certain information technology and computer application skills, integrate the difficult and important information into the terse and forceful video and design excises meeting the course needs, can the knowledge transmission with micro videos be unimpeded, so that teachers can track students' independent learning and knowledge mastery in real time. Similarly, only students master some computer application skills, can they use computer terminals, tablet PCs, smart phones and other mobile devices to complete independent learning before class and targeted training to identify the problem.

\subsection{To enhance students' ability to conduct independent learning}

The result of students' independent learning of micro video courses directly affects the implementation and effect of the knowledge internalization in the flipped classroom. The flipped classroom changes the traditional classroom teaching model. In the flipped classroom, teachers do not transfer knowledge to students in a non-reversing way; students explore knowledge by watching micro videos. This is a complete change and useful supplement of the knowledge transmission process, which puts forward higher requirements on students' independent ability and self-discipline. Before class, students become the regulator to adjust the learning pace by themselves. That means students choose learning time and space according to their learning situation to master the progress and pace of the learning content and learning volume. In the class, students are highly involved into exchanges and communication with teachers and other students, so they can expand and create new knowledge with a certain breadth and depth in the discussion. The improvement of students' independent learning ability and the development of individualized learning is beneficial to students in their whole life. It is the fundamental way to improve the effectiveness of college English teaching and the only choice to realize the change from school education to lifelong self-education for students.

\subsection{To carry out various forms of classroom activities}

The success of the flipped classroom in foreign universities has provided us with much beneficial experience. In the flipped classroom, the University of Miami uses podcasts, which include lecture content ranging from several minutes to tens of minutes. Students can review the lectures at any time via podcasts. The flipped classroom in the University of Puerto Rico consists of four parts: the slide, paired interactive excise module before class, lesson-oriented module for classroom discussion and problem-solving module after school. We can learn from their experience. Watching the video before the class allows students to learn the relevant knowledge and theory. If students want to truly master the knowledge, they should combine theory and practice to internalize the knowledge. The careful organization and reasonable arrangement of classroom activities is to the key for flipped classroom to receive good results. Class activities should be designed according to the characteristics of the subject. Humanities with many learning objectives are more involved in multidisciplinary knowledge and require teachers to communicate with students emotionally in order to achieve better results. For English, different teaching methods can be adopted for different learning content and learning objectives. For the study of vocabulary, the game and cooperative exploration can be used; for the teaching of novels and scripts, teachers can use context-based teaching, so that students can master knowledge through the role play; for the argumentation teaching materials, teachers can use group discussion and keynote speeches; for the description teaching materials, teachers can use cooperative inquiry and research reports. In the flipped classroom, students should become the subject of the independent learning and the true master of the learning.

\section{Summary}

The flipped classroom is not a simple overturn of the traditional classroom process. The more important thing is that the flipped classroom process realizes the student-centered teaching and 
students' independent learning ability has been significantly improved. This change and innovation has put forward higher requirements on teachers' professional competence and teaching ability. Teachers should change their concept and re-position their role. They should make wonderful videos and optimize classroom activities according to teaching objectives, so that the flipped classroom can be an ideal place for students' all-round development and growth.

\section{References}

[1] Li Jingnan, Wu Zhongjie. The Practice and Reflection on the Flipped Classroom of the College English [J]. Foreign Languages in China, 2015, (06): 4-9.

[2] Wu Zhenghong. An Analysis of the Application of the Flipped Classroom Model in College English teaching [J]. Journal of China Institute of Industrial Relations, 2015, (04): 121-125.

[3] Zhang Jie, Li Ke and Du Xiao. The Flipped College English Classroom: a Reflection Based on the Current Investigation [J]. Modern Educational Technology, 2015, (07): 68-74.

[4] Cheng Yongjun. A Discussion on the Flipped Classroom and Its Application in College English Teaching [J]. English Square, 2015, (04): 133-135.

[5] Song Xia. An Exploration of the Flipped Classroom in College English Teaching on the Basis of the Mobile Terminals [J]. Journal of Changjiang Engineering Vocational College, 2014, (04): 71-73.

[6] Cui Yanhui, Wang Yi. A Discussion on the Flipped Classroom and Its Application in College English Teaching [J]. China Education Technology , 2014, (11): 116-121.

[7] Wang Binhong. A Discussion on the Application of the Flipped Classroom in College English Teaching [J]. College English (Academic Edition), 2014, (01): 9-12. 